\title{
Effectiveness Application of Local Wisdom Ecological Modules Kasepuhan Cisungsang Community Through Utilization of Ecosystems on Student Learning Outcomes of $\mathbf{1 0}^{\text {th }}$ Class in Senior High School
}

\author{
Aditya Rahman ${ }^{1)}$, Nurul Anisa ${ }^{2)}$, Bambang Ekanara ${ }^{3)}$ \\ Faculty of Teacher Training and Education, University of Sultan Ageng Tirtayasa, Indonesia. \\ email: adityaarahman9@gmail.com
}

\begin{abstract}
This study aimed to analyze the implementation of learning module of ecology based on local wisdom of society in Kasepuhan Cisungsang. This research and development study was conducted in small scale involving 30 students on SMAN 1 Petir, Serang, Banten. Simple random sampling was used for sampling methods. Instruments for data collections were using objective test, reflection journal, observation sheet and questionnaire. The effectivity of module was rated based on student learning completeness (grade > 65). The result showed $83 \%$ of students have completed in cognitive assessment, $87 \%$ of students have completed in psychomotor assessment. Questionnaire for student response showed the average value of $43 \%$ in very good category and $57 \%$ in good category. It can be concluded that the learning modules effective to facilitate student learning outcomes.
\end{abstract}

Keywords: Ecology, Effectiveness, Learning Module, Learning outcomes, Local wisdom

\section{INTRODUCTION}

Learning is two ways of communication process which are teaching and learning. There are number of values that must be conveyed to students. These values are taken from various sources and presented as learning material. Learning material are source of informations, tools and/or texts needed by teacher to plan and review the implementation of learning (Majid, 2005: 174). The form of printed learning sources are handout, books, module, worksheet, brochure, pamphlet, wallchart, drawing and model.

Many research has been conducted to produce or develop learning materials tailored to basic competencies. This study was to test the effectivenes of learning source in the form of module. The module was on ecology with the insight of local wisdom from Kasepuhan Cisungsang community. The module was developed by Nurendah (2017) using research and development (R\&D) method. The average value of the developed module's feasibility was $93 \%$ or in the very feasible category. A value of $96 \%$ gained from media expert validation or in very valid category. It means that the developed module fulfilled all the qualification as valid and feasible product.
The purpose of developing the module which adopt the local wisdom of the society in Kasepuhan Cisungsang was to help students learning and facilitate the transfer of knowledge particularly in the subject matter of ecology. This has been inline with The Indonesian Law number 20 in the year of 2003 about National Education System on chapter $X$ article 36 verse 3 point $c$ which stated that the curriculum is prepared by considering the diversity of regional and environmental potential.

Before a product of development can be applied widely, several limited trials are required to determine its effectiveness. Limited trials test the product in the terms of student learning outcomes and the difficulties experienced by the teacher in managing learning (Sanjaya, 2011).

Research and Development study is a logitudinal or sustainable study because it must pass various types of tests and product revisions before being used for large scale. In the module developed by Nurendah (Nurendah, 2017), limited trials have not been conducted.

Many printed product of $R \& D$ studies have not been tested through limited trials so that their effectiveness and efficiency are not measurable yet. Those will be a weak point and a lack of the products. Therefore,

Bioedukasi Vol. XVII. No. 1 April 2019 
conducting the complete test for developed products are necessary to guarantee the quality of the products. This is in accordance with the main purpose of learning using modules which is to improve the efficiency and effectiveness of learning in schools, both time, funds, facilities, and energy to achieve goals optimally (Mulyasa, 2013).

Based on this background, it is necessary to conduct study that aims to determine the effectiveness and response of students regarding the application of module in ecology with insight of the local wisdom of Cisungsang community.

\section{RESEARCH METHOD}

This study was conducted at Petir 01 senior highschool in the academic year of $2017 / 2018$ on the $10^{\text {th }}$ grade students. Time of the study was at $2^{\text {nd }}-9^{\text {th }}$ May of 2018. The respondents were from the class of X MIA 3.

Simple random sampling was used as sampling technic. Kognitive aspect was measured by objective test which consist of 18 items starting from cognitive level of $\mathrm{C} 1$ up to C4. For psychomotor aspect, measurement was carried out using observation sheet. Furthermore a questionnaire also used to measure students respons after being taught using the module.

\section{RESULT AND DISCUSSION}

A. Students Cognitive Achievement

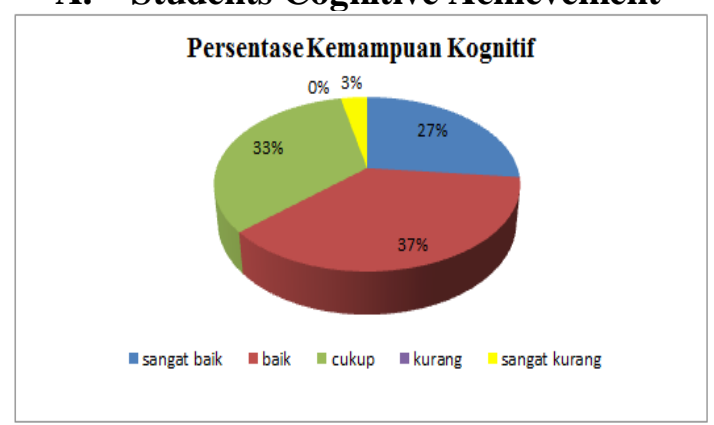

Figure 1. Result of cognitive measurement

Students' cognitive abilities were measured using objective tests in the form of 18 multiple choice questions made based on 5 learning indicators. The results of the data can be seen in Figure 1. Based on Basic of Competence No. 3.10, students are expected to be able to analyze information / data from various sources about the ecosystem and all interactions that take place in it. This basic of competence then derived into 5 learning indicators. The results of students' cognitive abilities based on each indicator are shown in Figure 2.

Based on Figure 2, the average value of cognitive abilities in indicator 3 is the highest compared to the average value of other cognitive indicators. This is because there is a scientific article about "water cycle" in the module which gave students an initial understanding of the biogeochemical cycle.

This is in line with the opinion of Djamarah \& Zain, (2006) which states that the preliminary stage can encourage student learning activities optimally and increase students learning motivation. Improvement was then made to support the content of local wisdom by the new article of "Efficiency in the Use of Nitrogen in Different Types of Vegetation at the Cikaniki Research Station, Halimun Mountain, Salak National Park, West Java".

Based on the results of the student response questionnaire, the explanation of the material is quite clear and also supported by relevant images. There is an exploration and discussion column as well in the module about "the importance of the biogeochemical cycle for life". In that column students were asked to discuss in groups to determine the imbalance of ecosystem components and biogeochemical cycles in real life. At the bottom of the exploration and discussion column, there is a web link that contains additional information about the biogeochemical cycle to make it easier for students to access information via the internet. The lowest grade was on learning indicator number 4.

Based on the teacher reflective journal, there were students who weren't cooperative during re-reading and discussion, this lead to failure during question and answer stage. Another reason of the failure was the weakness on the talking stick method used in the learning activity. Some students were afraid of being questioned, they were mentally unprepared to speak in front of the class. The method might be unsuitable (Suprijono, 2009). 


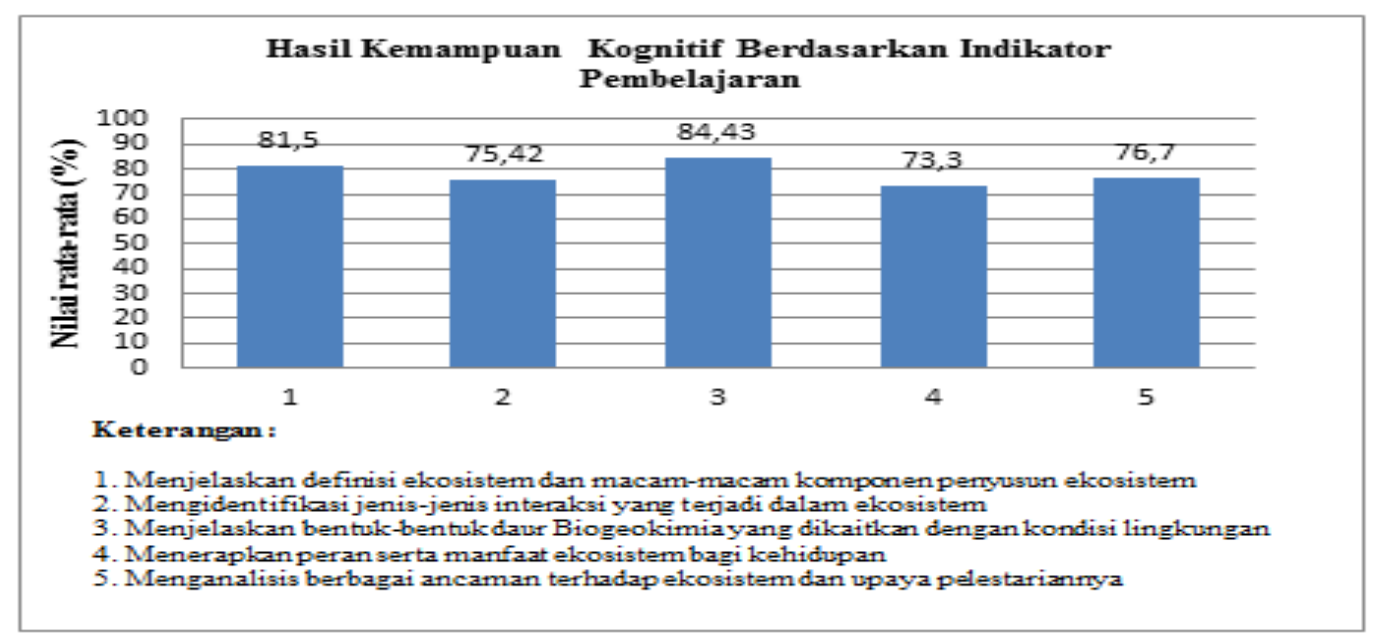

Figure 2. Students cognitive achievements based on learning indicators

\section{B. Students Psychomotor Ability}

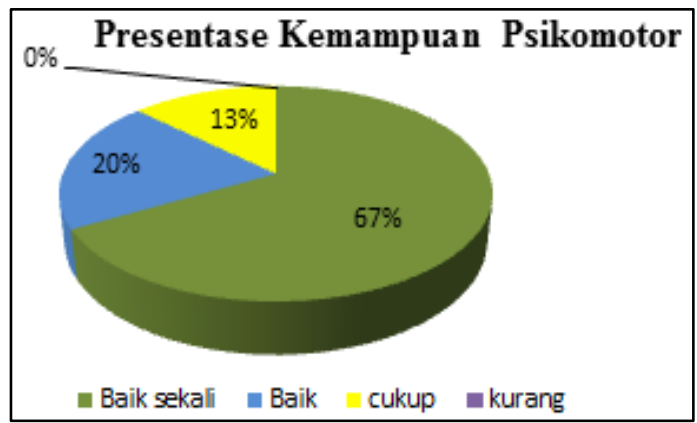

Figure 3. Result of Psychomotor Measurement

Students' psychomotor abilities were measured using observation sheet. In the module there are four work activities that can be carried out, including: (1) direct observation of the ecosystem; (2) create an ecosystem model to understand interactions between components and the food chain; (3) observing the use of ecosystems in the environment; and (4) making video threats and their conservation efforts in the surrounding environment.

The percentage can be seen in Figure 4, while the students' psychomotor abilities are shown in Figure 5. The first psychomotor indicator got an average value smaller than the average value of the second psychomotor indicator. Measurement for $1^{\text {st }}$ indicator was done at the first meeting for direct observation. Students in groups made observations to know the ecosystem and to distinguish ecosystem components in the school environment, students then discussed and presented their observations.

Next, students made a tettarium model outside the school which was observed for 2 days, the observation results then written in individual report. The format of written reports on average were in accordance with the format given but students lack of deep reasoning in the discussion section. This is because students are not accustomed to make observational reports, especially on biology subjects and this assignment becomes a new learning experience for students.

Mufit et al. (2013) said that report writing affects the Physics learning outcomes of psychomotor because by writing a written report students practice imitation skills in the psychomotor domain, by writing written reports students not only see the process but also understand the concept better.

The second indicator gets the highest average value. The measurement of the second indicator was done outside the biology class. Students discussed in advance to look for threats to the ecosystem in the surrounding environment, then make videos containing threats and efforts to preserve the ecosystem in groups. This 1 week assignment was given outside of class schedule, then after making a video, students presented the video.

According to Munadi (2010), learning videos that record students' motoric activities provide an opportunity for them to observe and evaluate their practical work, both personally and feedback from their friends. This is in line with the results of a

Bioedukasi Vol. XVII. No. 1 April 2019 
study by Zaenudin, et al. (2010) that the use of science learning videos was generally in great demand by all MIN Kroya students, and could improve student learning outcomes in human digestive material. Suyanto \& Handziko (2015) also found that the use of
Merapi ecosystem succession video after the 2010 eruption was proven to help students understand the succession process.

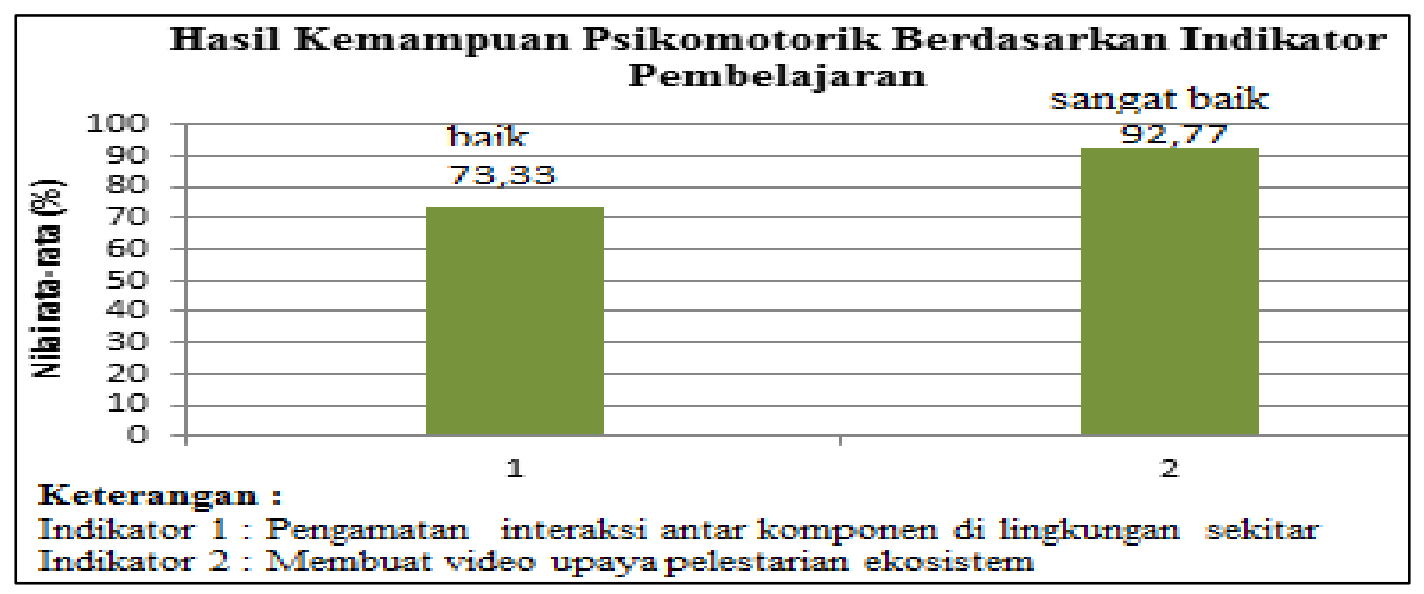

Figure 4. Student psychomotor achievement based on learning indicators.

\section{Students respons questionnaire}

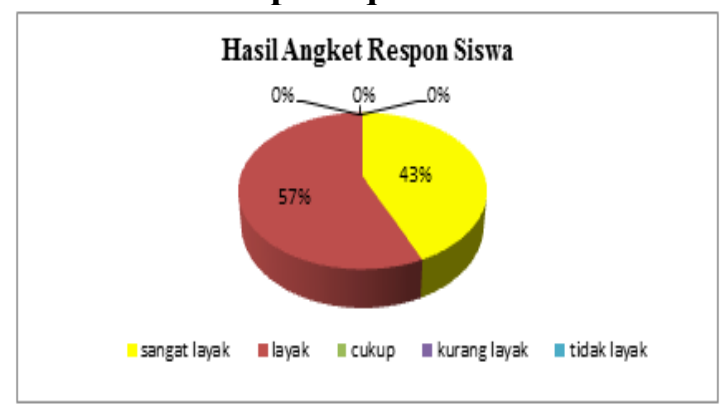

Figure 5. Students response questionnaire percentage.

Student responses were measured using questionnaires in the form of 28 statements which consisted of 14 positive statements and 14 negative statements. Student response data as shown in Figure 5. while the results of 6 aspects of data processing on student response questionnaires are shown in Figure 6. Based on the results it is known that the largest average value was in local wisdom content. This is because the module provides images from contextual personal documentation that describe the ecological conditions that are still awake and have not been maintained.
In addition, the module was also equipped with additional informations about the local wisdom of the Kasepuhan Cisungsang community which add knowledge for students while evoking students' interest in learning. Snively \& Corsiglia (2001) said that the use of local wisdom content in learning, besides being able to save the knowledge of local wisdom itself, also increases students' concern about biodiversity and conservation.

The lowest average value was the aspect of language level. Based on student response questionnaires, the sentences presented in the module were clear and there were explanations that help students comprehension. But there were still writing errors (typo), and the writing of alternative answers was less consistent, there were questions that have 4 alternative answers and 5 alternative answers. According to the question writing guide for highschool (2017) alternative answers provided for high school level are 5 choices. 


\section{Hasil Angket Respon Siswa}

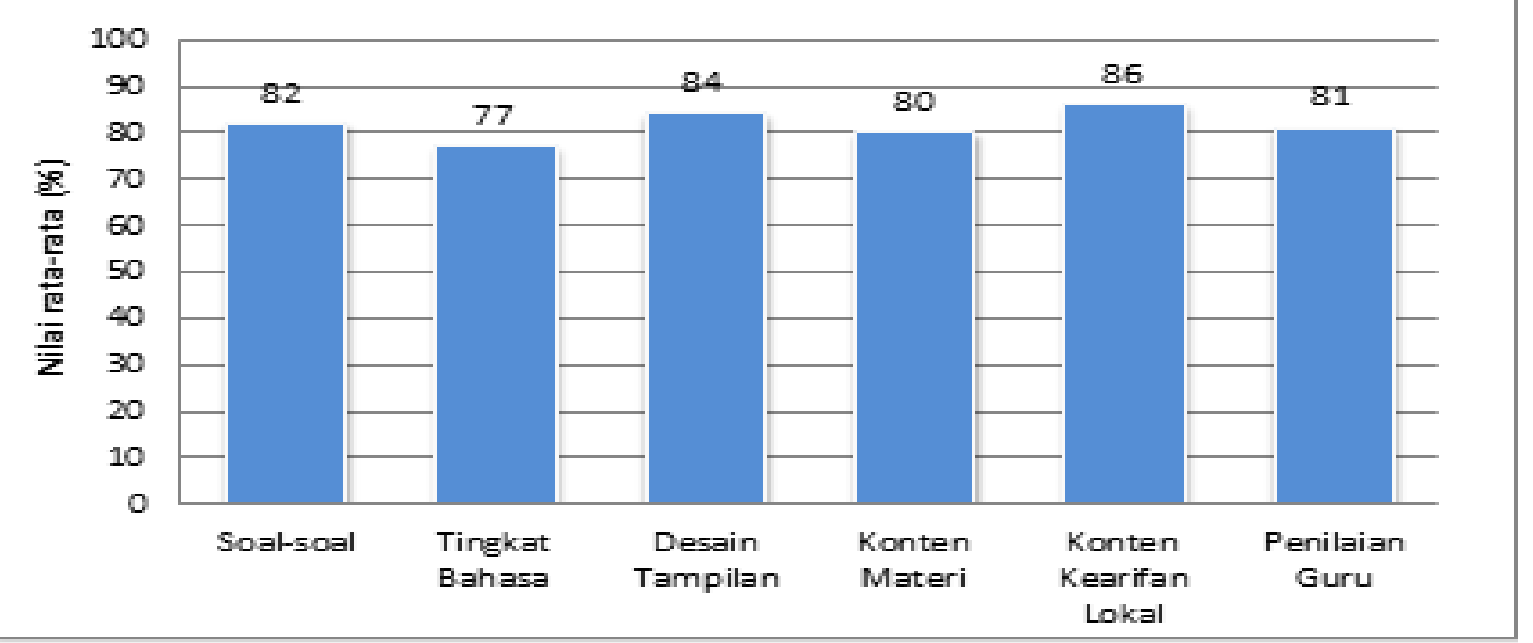

Figure 6. Average scores of students respons questionnaire aspects.

\section{The Effectivity of The Module}

The developed learning module is said to be effective if $80 \%$ of students have finished, and can be said to be complete if the value achieved is more than minimal standart (KKM) (Muhafid et al., 2014). The results of student learning completeness in the cognitive and psychomotor domains can be seen in Figure 7.

Based on the results of the cognitive domain, there were 25 students who scored above the KKM and 5 students who scored below the KKM. This means that $83 \%$ of students are said to be complete and $17 \%$

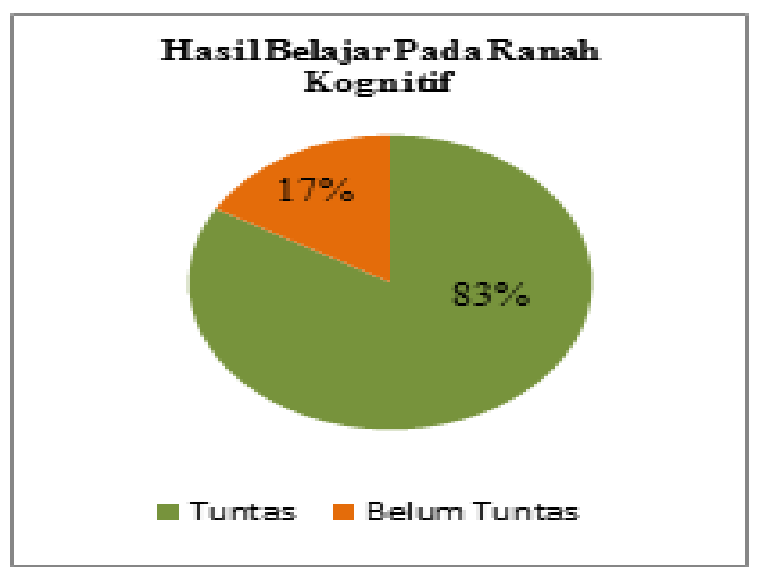

of students are declared incomplete (Appendix 8). Then in the psychomotor domain, there were 26 students who scored above the KKM and 4 students who scored below the KKM. This means that $87 \%$ of students were declared complete and $13 \%$ of students were declared incomplete (Appendix 11). Therefore, it can be concluded that the learning module developed has been effective on student learning outcomes.

Figure 7. The percentage of cognitive and psychomotor achievements. 


\section{CONCLUSION}

Based on the results, it can be seen that in the cognitive aspects as much as $83 \%$ of students have been completed in learning and in the psychomotor aspects of $87 \%$ of students have completed learning. Whereas based on the results of the student response after using the specified developed module, it can be seen that $43 \%$ of students stated that it was very feasible and $57 \%$ of students said it was feasible to be used as teaching materials. So that it can be concluded that the learning module developed is effective on learning outcomes.

\section{REFERENCES}

Aditya, R., Ika, R., Indria W., 2017. Pengaruh Metode Field Trip Dengan Pemanfaatan Rumpon Buatan Terhadap Keterampilan Proses Sains Dan Sikap Ilmiah Di SMP Satu Atap Pulau Tunda. Biodidaktika 12 (1): 28 hlm.

Djamarah, S. B \& A. Zain. 2006. Strategi belajar mengajar. Rineka cipta, Jakarta: xi+226 hlm.

Majid, A. 2005. Perencanaan Pembelajaran. Rosda. Bandung: ix + $291 \mathrm{hlm}$.

Mufit, F., Ramli, E., Yance, R. D. 2013. Pengaruh Penerapan Model Project Based Learning (PBL) Terhadap Hasil Belaar Fisika Siswa Kelas XI IPA SMA Negeri 1 Batipuh Kabupaten Tanah Datar. Pillar of physics education 1 (1).

Muhafid, E. A., Dewi, N.R \& Widiyatmoko, A. 2013. Pengembangan LKS IPA Terpadu Pendekatan Keterampilan Proses pada Tema Bunyi di SMP Kelas VII. Unnes science educational journal. 2 (1): 140-148.
Mulyasa, H. E. 2013. Pengembangan Dan Implementasi Kurikulum 2013. Remaja Rosda Karya, Bandung: vii + $231 \mathrm{Hlm}$.

Nurendah, N. 2017. Pengembangan Modul Ekologi Berwawasan Kearifan Lokal Masyarakat Kasepuhan Cisungsang Melalui Pemanfaatan Ekosistem untuk Pembelajaran Biologi SMA/MA Kelas X. [skripsi]. Pendidikan Biologi. Universitas Sultan Ageng Tirtayasa. $\mathrm{V}+182 \mathrm{Hlm}$.

Sanjaya, W. 2011. Perencanaan \& Desain Sistem Pembelajaran. Kencana. Jakarta: xvi + 284 Hlm.

Snively, G., \& Corsiglia, J. 2001. Discovering Indigenous Science: Implication for Science Education. Science Education, LXXX, 6-34.

Suprijono, A. 2009. Cooperative Learning. Surabaya: Pustaka pelajar.

Suyanto, S \& Handziko, R. C. 2015. Pengembangan Video Pembelajaran Suksesi Ekosistem Untuk Meningkatkan Motivasi Belajar dan Penguasaan Konsep Mahasiswa Biologi. Jurnal Inovasi Pendidikan IPA. 1 (2).

Zaenudin, A., Udin, T., Busyaeri, A. 2010. Pengaruh Penggunaan Video Pembelajaran Terhadap Peningkatan Hasil Belajar Mapel IPA di MIN Kroya Cirebon. Jurnal pendidikan IPA. 2 (1).

Bioedukasi Vol. XVII. No. 1 April 2019 